\title{
Permasalahan Yang Dialami Lansia Dalam Menyesuaikan Diri Terhadap Penguasaan Tugas-Tugas Perkembangannya
}

\author{
Afrizal \\ Institute Agama Islam Negeri (IAIN) Curup \\ Afrizalriza28@gmail.com
}

\begin{abstract}
The purpose of this study is to describe and illustrate the problems experienced by the elderly in mastering development tasks. This research is a research field that is qualitative, descriptive. From the results of research can be in the know that, physical strength and health is a major problem that is often faced by the elderly, because the family needs still great while power on the wane so what generated the leter insufficient, retirement is not a lot of problems arise that relate to economic families in meeting the daily needs, the problem of death of spouse is a very heavy problems perceived by the elderly because they often living areas a sense of loneliness and changing roles between them, in forming a relationship with people at not too experienced obstacles, because the elderly usually often follows the recitation or arisan, problems associated with the broader social role is not too experienced a lot of problems, because the elderly are still arriving by the whole community.
\end{abstract}

Key words: Problems of the Elderly, Adjust, Developmental Tasks

\begin{abstract}
Abstrak
Tujuan dari penelitian ini adalah untuk mendeskripsikan dan menggambarkan permasalahan yang dialami lansia dalam penguasaan tugas-tugas perkembangannya. Penelitian ini merupakan penelitian lapangan yang bersifat deskriptif kualitatif. Dari hasil penelitian dapat di ketahui bahwa, kekuatan fisik dan kesehatan merupakan masalah utama yang sering dihadapi lansia, karena kebutuhan keluarga masih besar sedangkan tenaga semakin berkurang sehingga apa yang dihasilkan nantinya kurang maksimal, memasuki masa pensiun tidak banyak timbul permasalahan yang berhubungan dengan ekonomi keluarga dalam memenuhi kebutuhan sehari-hari, masalah kematian pasangan hidup merupakan permasalahan yang sangat berat dirasakan oleh para lansia karena mereka sering dihinggapi rasa kesepian dan terjadi perubahan peran diantara mereka, dalam membentuk hubungan
\end{abstract}


dengan orang-orang seusia tidak terlalu mengalami hambatan, karena lansia biasanya sering mengikuti pengajian ataupun arisan, permasalahan yang berhubungan dengan peran sosial yang lebih luas tidak terlalu mengalami banyak masalah, sebab lansia masih di terima oleh segenap masyarakat.

Kata Kunci: Permasalahan Lansia, Menyesuaikan Diri, Tugas-tugas Perkembangan

\section{Pendahuluan}

Proses perkembangan manusia setelah di lahirkan secara fisiologis semakin lama menjadi lebih tua. Dengan pertambahan usia, maka jaringanjaringan dan sel-sel menjadi tua. Sebagian regenerasi dan sebagian yang lain akan mati ${ }^{1}$. Usia enam puluh di pandang sebagai garis pemisah antara usia dewasa madya dan usia lanjut. Pada masa usia lanjut tidak dapat digambarkan dengan jelas karena setiap individu berbeda-beda. Sikap-sikap sebelumnya, situasi kehidupan, dan kekuatan fisik mempengaruhi penyesuaian diri pada tahap terakhir kehidupan ini.

Masalah-masalah utama dan penyebab gangguan kepribadian pada masa usia lanjut adalah keterbatasan fisik yang sangat ketat, ketergantungan perasaan semakin kurang berguna, dan perasaan terisolasi. ${ }^{2}$ Pada usia lanjut ini, biasanya akan menghadapi berbagai macam persoalan. Persoalan pertama adalah penurunan kemampuan fisik sehingga kekuatan fisik berkurang, aktivitas menurun, sering mengalami gangguan kesehatan yang menyebabkan mereka kehilangan semangat. pengaruh dari semua itu, mereka yang berada dalam usia lanjut merasa dirinya tidak berharga lagi atau kurang di hargai.

Manusia usia lanjut atau lansia dalam pemikiran banyak orang adalah manusia yang sudah tidak produktif lagi. Kondisi fisik rata-rata sudah menurun, sehingga dalam kondisi yang sudah uzur ini berbagai penyakit siap untuk menyerang mereka. Dengan demikian, di usia lanjut ini terkadang muncul semacam pemikiran bahwa mereka berada pada sisa-sisa umur menunggu datangnya kematian. Memasuki masa tua, sebagian besar lanjut usia kurang siap menghadapi dan menyikapi masa tua tersebut, sehingga menyebabkan para lanjut usia kurang dapat menyesuaikan diri dan memecahkan masalah yang dihadapi

Menurut Erickson, kesiapan lansia untuk beradaptasi atau menyesuaikan diri terhadap tugas perkembangan usia lanjut dipengaruhi oleh proses tumbuh kembang pada tahap sebelumnya. Apabila seseorang pada tahap tumbuh kembang sebelumnya melakukan kegiatan sehari-hari dengan teratur dan baik serta membina hubungan yang serasi dengan orang-orang di sekitarnya, maka

\footnotetext{
${ }^{1}$ Surunin, Imu Jiwa Agama, (Jakarta: Raja Grafindo Persada, 2004), hal. 88.

${ }^{2}$ Yustinus semium ofm, Kesehatan Mental, (Yogyakarta:Kanisius, 2006), hal. 309-310.
} 
pada usia lanjut ia akan tetap melakukan kegiatan yang biasa ia lakukan pada tahap perkembangan sebelumnya seperti olahraga, mengembangkan hobi bercocok tanam dan lain-lain. ${ }^{3}$

Dari beberapa pengertian diatas menerangkan bahwa penyesuaian diri pada lanjut usia adalah kemampuan orang yang berusia lanjut untuk menghadapi tekanan atau konflik akibat perubahan-perubahan fisik, maupun sosialpsikologis yang dialaminya dan kemampuan untuk mencapai keselarasan antara tuntutan dari dalam diri dengan tuntutan dari lingkungan, yang disertai dengan kemampuan mengembangkan mekanisme psikologis yang tepat sehingga dapat memenuhi kebutuhan- kebutuhan dirinya tanpa menimbulkan masalah baru.

Masalah khusus yang timbul pada lansia adalah karena mereka tidak mampu menyelesaikan tugas perkembangannya dengan baik. Secara garis besar menurut Havighurst tugas-tugas perkembangan usia lanjut adalah sebagai berikut:

1. Menyesuaikan diri dengan menurunnya kekuatan fisik dan kesehatan.

2. Menyesuaikan diri dengan masa pensiun dan berkurangnya income (penghasilan) keluarga.

3. Menyesuikan diri dengan kematian pasangan hidup.

4. Membentuk hubungan dengan orang-orang yang seusia.

5. Membentuk pengaturan fisik yang memuaskan

6. Menyesuaikan diri dengan peran sosisl yang luas.

Melihat fenomena yang terjadi sekarang ini kebanyakan lansia yang mengalami kegagalan dalam tugas perkembangannya. Dari hasil wawancara dengan beberapa orang lansia yang ada di Kelurahan Pasar Tengah menyesuaikan diri dengan menurunnya kekuatan fisik dan kesehatan merupakan faktor pertama yang menjadi masalah salah satu contohnya adalah perubahan fisik pada lanjut usia mengakibatkan dirinya merasa tidak dapat mengerjakan berbagai aktivitas sebaik pada saat muda dulu. Hal ini menyebabkan lanjut usia kemudian menjadi demotivasi dan menarik diri dari lingkungan sosial. Masalahmasalah lain yang terkait pada usia ini antara lain, perasaan tidak berguna, keinginan untuk cepat mati atau bunuh diri, dan membutuhkan perhatian lebih. Masalah-masalah ini dapat membuat harapan hidup pada lanjut usia menjadi menurun. Perlu digaris bawahi pada lanjut usia adalah bahwa meraih usia panjang tidak hanya soal menjaga kesehatan fisik, tetapi yang lebih penting adalah bagaimana mental seseorang dalam menyikapi rentang hidupnya.

Periode usia lanjut memiliki potensi untuk mengalami kebahagiaan pribadi. Pada masa ini waktu senggang banyak, dan tanggung jawab terhadap 
pekerjaan sehari-hari berkurang. ${ }^{4}$ Keluarga adalah tempat terbaik pada lansia untuk tinggal dan melewati hari tuanya, hidup bertempat tinggal dengan anaknya, cucu atau kerabat lain. Merawat lansia pada umumnya di lakukan anak perempuan mereka, terutama bagi masyarakat Indonesia yang berada di daerah pedesaan dan masih mempertahankan budaya extended family. Perubahan fisik, biologis dan psikologis yang terjadi pada lansia membuat mereka lebih beresiko untuk menjadi kurangnya perhatian keluarga terhadap para lansia.

Lansia sangat membutuhkan sekali peran serta dari keluarga untuk menangani masalan post power syndrome yaitu keadaan yang menimbulkan gangguan fisik, sosial dan spiritual pada lansia saat memasuki waktu pensiun sehingga dapat menghambat aktifitas mereka dalam menjalani kehidupan seharihari.

Menurut Hurlock menyatakan bahwa: Serangkaian perubahan fisik, sosial, maupun psikologis yang dialami selama proses menua membutuhkan kesiapan individu untuk menghadapinya. Perubahan-perubahan yang terjadi pada masa lanjut usia antara lain perubahan fisiologis, perubahan kemampuan motorik, dan perubahan sosial-psikologis. Efek-efek dari perubahan tersebut menentukan, apakah pria atau wanita lanjut usia (lansia) tersebut akan melakukan penyesuaian diri secara baik atau buruk

Hal-hal tersebut di atas yang dapat menjadi penyebab lanjut usia kesulitan dalam melakukan penyesuaian diri. Bahkan sering ditemui lanjut usia dengan penyesuaian diri yang buruk. Sejalan dengan bertambahnya usia, terjadinya gangguan fungsional, keadaan depresi dan paranoid akan mengakibatkan lanjut usia semakin sulit melakukan penyelesaian. Sehingga lanjut usia yang masa lalunya sulit dalam menyesuaikan diri cenderung menjadi semakin sulit penyesuaian diri pada masa-masa selanjutnya.

Berdasarkan latar belakang dan fokus penelitian yang disampaikan maka rumuskan pokok dalam penelitian ini adalah masalah apa yang dialami lansia dalam penguasaan tugas-tugas perkembangannya baik dalam menyesuaikan diri dengan menurunnya kekuatan fisik dan kesehatan, masa pensiun dan menurunnya penghasilan keluarga, kematian pasangan hidup, membentuk hubungan dengan orang-orang seusia, menyesuaikan dengan peran sosial yang luas.

\section{Konsep Dasar Usia Lanjut}

Siapa yang di sebut usia lanjut? Biasanya seseorang di golongkan ke kelompok usia lanjut berpedoman pada usia kalender, dan lazimnya bila ia menganjak usia 50-60 tahun. Namun usia kalender tidak selalu dihayati secara

\footnotetext{
${ }^{4}$ Elida Prayitno, Psikologi Orang Dewasa, (Padang: Fakultas Ilmu Pendidikan UNP, 2000), hal .83.
} 
sama oleh semua orang. Seseorang merasa dirinya tua atau jiwanya maupun cara orang lain memperlakukan serta norma sosial budaya terhadap proses menjadi tua.

Proses menua adalah suatu proses menghilangnya secara perlahan-lahan kemampuan jaringan untuk memperbaiki diri atau mengganti dan mempertahankan fungsi normalnya sehingga tidak dapat bertahan terhadap infeksi dan memperbaiki kerusakan yang diderita. ${ }^{5}$

\section{Batasan usia menurut WHO}

a. Usia pertengahan (middle age), yaitu kelompok usia 45 sampai 59 tahun

b. Lanjut usia (elderly), antara 60 sampai 74 tahun

c. Lanjut usia tua (old), antara 75 sampai 90 tahun

d. Usia sangat tua (very old), diatas 90 tahun

Menurut UU No. 4 tahun 1965 pasal 1 dinyatakan sebagai berikut : "Seorang dapat dinyatakan sebagai seorang jompo atau lanjut usia setelah yang bersangkutan mencapai umur 55 tahun, tidak mempunyai atau tidak berdaya mencari nafkah sendiri untuk keperluan hidupnya sehari-hari dan menerima nafkah dari orang lain". Saat ini berlaku UU No. 13 tahun 1998 tentang kesejahteraan lansia yang berbunyi sebagai berikut: lansia adalah seseorang yang mencapai usia 60 tahun ke atas.

Usia lanjut merupakan usia yang mendekati akhir siklus kehidupan manusia di dunia. Usia tahap ini di mulai 60-an sampai akhir kehidupan. Periode ini digambarkan dalam Al-Hadis sebagai berikut:

"Masa penuaan umur ummatku adalah enam puluh hingga tujuh puluh tahun." (HR Muslim dan Nasa i)

Mereka berkata; "ya Rasulullah, berapakah ketetapan umur-umur umatmu?" Jawaban beliau: "Saat kematian mereka (pada umumnya) antara usia enampuluh dan tujuh puluh. "Mereka bertanya lagi: "ya Rasulullah, bagaimana dengan umur delapan puluh?"Jawab beliau, "Sedikit sekali umatku yang dapat mencapainya. Semoga allah merahmatkan orang-orang yang mencapai umur delapan puluh". (HR Hudzaifah Ibn Yamani) ${ }^{6}$

Tahap usia ini adalah tahap dimana terjadi penuaan dan penurunan, yang penurunannya lebih jelas dan lebih dapat diperhatikan dari pada tahap usia baya. Penuaan merupakan perubahan kumulatif pada mahluk hidup, termaksud tubuh, jaringan dan sel-sel yang mengalami penurunan kapasitas fungsinya. Pada manusia penuaan di hubungkan dengan penuaan degeneratif pada kulit, tulang, jantung, pembuluh darah, paru-paru, saraf dan jaringan tubuh lainnya.

${ }^{5}$ Nugroho, perawatan lanjut usia, (Jakarta: EGC,1995) hal 28.

6 Aliyah B. Purwakania Hasan. Psikologi Perkembangan Islam, Jakarta:Raja Grapindo persada, 2006). hal 116 
Sebagian perubahan fisik yang biasanya diasosiasikan dengan penuaan dapat dilihat secara jelas melalui pengamatan biasa. Kulit mereka yang sudah menua menjadi memucat dan kurang elastis dan seiring dengan mengerutnya lemak dan otot, kulit tersebut bisa menjadi mengerut. Pembengkakan pembuluh darah di kaki menjadi hal yang paling umum. Rambut di kepala menjadi putih dan menjadi semakin tipis, dan rambut tubuh semakin berkurang. ${ }^{7}$

Periode selama usia lanjut, ketika kemunduran fisik dan mental terjadi secara perlahan dan bertahap pada waktu kompetensi terhadap penurunan ini dapat dilakukan, dikenal sebagai "senescence" yaitu masa proses menjadi tua. Seseorang akan menjadi orang semakin tua pada usia lima puluhan atau tidak sampai mencapai awal atau akhir usia enampuluhan, tergantung pada laju kemunduran fisik dan mentalnya. Pemunduran itu sebagian datang dari factor psikologis. Penyebab kemunduran fisik ini merupakan suatu perubahan pada selsel tubuh bukan karena penyakit khusus tapi karena proses menua. Kemunduran juga dapat mempunyai penyebab psikologis. Sikap tidak senang terhadap diri sendiri, orang lain, pekerjaan, dan kehidupan pada umumnya dapat menuju pada keadaan uzur, karena terjadi perubahan pada lapisan otak. Akhirnya, orang menurun secara fisik dan mental dan mungkin segera mati. Bagaimana seseorang mengatasi ketegangan dan stress hidup akan mempengaruhi laju kemunduran itu.

Demikian juga halnya bahwa motivasi memainkan peranan penting dalam kemunduran. Seseorang yang mempunyai motivasi rendah untuk mempelajari hal-hal baru, atau ketinggian dalam penampilan, sikap atau pola prilaku, akan semakin memburuk lebih cepat dari pada orang yang mempunyai motivasi yang kuat. Masa luang yang baru akibat tumbuhnya masa pensiun sering membawa kebosanan yang semakin memperkecil dan melemahkan motivasi seseorang.

Sebagian besar tugas perkembangan usia lanjut lebih banyak berkaitan dengan kehidupan pribadi seseorang dari pada kehidupan orang lain. Orang tua diharapkan untuk menyesuaikan diri dengan menurunnya kekuatan, dan menurunnya kesehatan secara bertahap. Hal ini sering diartikan sebagai perbaikan dan perubahan peran dilakukan di dalam maupun di luar rumah. Mereka juga diharapkan untuk mencari kegiatan untuk mengganti tugas-tugas terdahulu yang menghabiskan sebagian besar waktu kala mereka masih muda.

Akibatnya dari menurunya tingkat kesehatan dan pendapatan, maka mereka perlu menjadwalkan dan menyusun kembali pola hidup yang sesuai dengan keadaan saat itu, yang sering sangat berbeda dengan apa yang dilakukan pada masa lampau. Cepat atau lambat, sebagian besar orang berusia lanjut perlu mempersiapkan dan menyesuaikan diri dengan peristiwa kematian suami atau 
istri. Kejadian seperti ini jauh lebih menjadi masalah bagi wanita dibandingkan pria. Kematian suami bagi wanita sering berarti berkurangnya pendapatan dan timbulnya bahaya karena hidup sendiri, sehingga perlu melakukan perubahan dalam aturan hidup.

Dua dari sekian banyak tugas perkembangan yang sulit pada masa usia lanjut berkaitan dengan bidang yang juga penting bagi setiap orang dewasa, yaitu pekerjaan dan kehidupan keluarga. Pada umumnya para usia lanjut mempunyai masalah dalam penyesuaian diri terhadap kedua bidang tersebut, yang juga pernah mereka hadapi pada masa kehidupan sebelumnya, sekalipun pada masa sekarang sifatnya lebih unik. Misalnya, mereka tidak hanya menyesuaikan diri dengan kondisi pekerjaan saja, tapi mereka juga harus menyadari bahwa manfaat dirinya bagi majikan semakin berkurang sesuai dengan semakin bertambahnya usia. Akibatnya, statusnya dalam kelompok kerja semakin berkurang. Dan lagi mereka juga mengalami kesulitan dalam menyesuaikan diri terhadap masa pensiun, dimana bagi sebagian besar para lanjut usia, pensiun tersebut terasa datang lebih cepat setelah memasuki usia lanjut.

Dalam keluarga, pria dan wanita usia lanjut harus dapat menyesuaikan diri untuk saling bergantung satu sama lainnya demi terjadinya suatu bentuk persahabatan yang akrab. Kurangnya kontak dan pengaruh terhadap anakanaknya, sering terjadi karena salah satu anggota pasangan tersebut ditinggal mati oleh pasangannya. Orang usia lanjut yang tidak menikah sering menghadapi masalah yang lebih serius dari pada menyesuaikan diri, ketimbang mereka yang menikah atau mereka yang ditinggal mati oleh pasangannya.

Penyesuaian diri terhadap pekerjaan dan keluarga bagi orang usia lanjut adalah sulit karena hambatan ekonomis yang dewasa ini sangat memainkan peranan penting ketimbang masa sebelumnya. Walaupun ada bantuan keuangan dari pemerintah dalam bentuk jaminan sosial, untuk membantu orang usia lanjut, bantuan kesehatan, dan pembagian keuntungan secara bertahap yang diperoleh dari dana pensiun, dan dari perusahaan, mereka kadang-kadang tidak sanggup mengatasi berbagai problem yang mereka hadapi.

Tugas perkembangan adalah tugas-tugas yang muncul pada periode tertentu dalam hidup. Jika kita berhasil menyelesaikannya maka akan membawa kebahagiaan dan membantu penyelesaian tugas perkembangan selanjutnya. Sedangkan jika gagal diselesaikan akan mengakibatkan ketidakbahagiaan, penolakan dari lingkungan, dan kesulitan dalam menghadapi tugas perkembangan selanjutnya.

\section{Penyesuaian Usia Lanjut}

Sebagian besar tugas perkembangan usia lanjut lebih banyak berkaitan dengan kehidupan pribadi seseorang dari pada kehidupan orang lain. Orang tua diharapkan untuk menyesuaikan diri dengan menurunnya kekuatan, hal ini 
sering diartikan sebagai perbaikan dan perubahan peran yang pernah dilakukan di dalam maupun di luar rumah. Mereka juga diharapkan untuk mencari kegiatan untuk mengganti tugas-tugas terdahulu yang menghabiskan sebagian besar waktu kala mereka masih muda.

Bagi beberapa orang usia lanjut, kewajiban untuk menghadiri rapat yang menyangkut kegiatan sosial dan kewajiban sebagai warga negara sangat sulit dilakukan karena kesehatan dan pendapatan merekan menurun setelah pensiun. Akibatnya, mereka sering terpaksa mengundurkan diri dari kegiatan sosial.

Akibatnya dari menurunya tingkat kesehatan dan pendapatan, maka mereka perlu menjadwalkan dan menyusun kembali pola hidup yang sesuai dengan keadaan saat itu, yang sering sangat berbeda dengan apa yang dilakukan pada masa lampau. Cepat atau lambat, sebagian besar orang berusia lanjut perlu mempersiapkan dan menyesuaikan diri dengan peristiwa kematian suami atau istri. Kejadian seperti ini jauh lebih menjadi masalah bagi wanita dibandingkan pria. Kematian suami bagi wanita sering berarti berkurangnya pendapatan dan timbulnya bahaya karena hidup sendiri, sehingga perlu melakukan perubahan dalam aturan hidup.

\section{Tugas-tugas Perkembangan Lansia}

Tugas perkembangan adalah tugas-tugas yang muncul pada periode tertentu dalam hidup. Jika kita berhasil menyelesaikannya maka akan membawa kebahagiaan dan membantu penyelesaian tugas perkembangan selanjutnya. Sedangkan jika gagal diselesaikan akan mengakibatkan ketidakbahagiaan, penolakan dari lingkungan, dan kesulitan dalam menghadapi tugas perkembangan selanjutnya.

Sebagian besar tugas perkembangan usia lanjut lebih banyak berkaitan dengan kehidupan pribadi seseorang dari pada kehidupan orang lain. Orang tua diharapkan untuk menyesuaikan diri dengan menurunya kekuatan, hal ini sering diartikan sebagai perbaikan dan perubahan peran yang pernah dilakukan didalam mamupun diluar rumah. Mereka juga diharapkan untuk mencari kegiatan untuk mengganti tugas-tugas terdahulu yang menghabiskan sebagian besar waktu kala mereka masih muda.

Bagi Erikson, prestasi puncak masa dewasa akhir adalah perasaan akan adanya integritas ego (ego integrity), atau integritas diri, pencapaian yang didasarkan pada refleksi akan kehidupan seseorang. Para lansia harus mengevaluasi, merangkum dan menerima kehidupan mereka untuk menerima semakin mendekatnya kematian. Orang yang sukses dalam tugas akhir bersifat integrative ini akan merasakan keteraturan dan makna hidup mereka dalam tatanan social yang lebih besar di masa lalu, sekarang dan masa depan. ${ }^{8}$

${ }^{8}$ Diane E. Papalia, Dkk, Human Development ( Psikologi Perkembangan),Jakarta: Kencana, 2008), hal. 845 
Secara garis besar menurut Havighurst tugas-tugas perkembangan usia lanjut adalah sebagai berikut:

a. Menyesuaikan diri dengan menurunnya kekuatan fisik dan kesehatan.

b. Menyesuaikan diri dengan masa pensiun dan berkurangnya income (penghasilan) keluarga.

c. Menyesuaikan diri dengan kematian pasangan hidup.

d. Membentuk hubungan dengan orang-orang yang seusia.

e. Menyesuaikan diri dengan peran sosial.

\section{Permasalahan Usia Lanjut}

Masalah umum yang dialami lanjut usia yang berhubungan dengan kesehatan fisik, yaitu rentannya terhadap berbagai penyakit, karena berkurangnya daya tahan tubuh dalam menghadapi pengaruh dari luar. Ditemukan bahwa lanjut usia menderita berbagai penyakit yang berhubungan dengan ketuaan antara lain diabetes melitus, hipertensi, jantung koroner, rematik dan asma sehingga menyebabkan aktifitas bekerja terganggu Penurunan kondisi fisik lanjut usia berpengaruh pada kondisi psikis.

Dengan berubahnya penampilan, menurunnya fungsi panca indra menyebabkan lanjut usia merasa rendah diri, mudah tersinggung dan merasa tidak berguna lagi. kondisi kesehatan mental lanjut usia mempengaruhi berbagai kondisi lanjut usia yang lain seperti kondisi ekonomi, yang menyebabkan orang lanjut usia tidak dapat bekerja untuk mencukupi kebutuhan hidupnya dan kondisi sosial yang menyebabkan kurangnya hubungan sosial antara lanjut usia dengan masyarakat. Masalah ekonomi yang dialami orang lanjut usia adalah tentang pemenuhan kebutuhan hidup sehari-hari seperti kebutuhan sandang, pangan, perumahan, kesehatan, rekreasi dan sosial.

Dengan kondisi fisik dan psikis yang menurun menyebabkan mereka kurang mampu menghasilkan pekerjaan yang produktif. Disisi lain mereka dituntut untuk memenuhi berbagai macam kebutuhan hidup sehari-hari yang semakin meningkat dari sebelumnya, seperti kebutuhan akan makanan bergizi seimbang, pemeriksaan kesehatan secara rutin, perawatan bagi yang menderita penyakit ketuaan dan kebutuhan rekreasi. Sedangkan penghasilan mereka antara lain dari pensiun, tabungan, dan bantuan keluarga. Bagi lanjut usia yang memiliki asset dan tabungan cukup, tidak terlalu banyak masalah. Tetapi bagi lanjut usia yang tidak memiliki jaminan hari tua dan tidak memiliki aset dan tabungan yang cukup maka pilihan untuk memperoleh pendapatan jadi semakin terbatas. Jika tidak bekerja berarti bantuan yang diperoleh mereka dapatkan dari bantuan keluarga, kerabat atau orang lain.

Dengan demikian maka status ekonomi orang lanjut usia pada umumnya berada dalam lingkungan kemiskinan. Keadaan tersebut akan mengakibatkan 
orang lanjut usia tidak mandiri, secara finansial tergantung kepada keluarga atau masyarakat bahkan pemerintah.

Bertitik tolak dari penjelasan di atas, maka beberapa masalah utama yang dihadapi lanjut usia pada umumnya adalah :

a. menurunnya daya tahan fisik.

b. masa pensiun bagi lanjut usia yang dahulunya bekerja sebagai pegawai negeri sipil yang menyebabkan menurunya pendapatan dan hilangnya prestise.

c. perkawinan anak sehingga anak hidup mandiri dan terpisah dari orang tua.

d. urbanisasi penduduk usia muda yang menyebabkan lanjut usia terlantar.

e. kurangnya dukungan dari keluarga lanjut usia.

f. pola tempat tinggal lanjut usia; lanjut usia yang hidup di rumah sendiri, tinggal bersama dengan anak atau menantu, dan tinggal di panti werdha.

\section{Permasalahan menurunya kekuatan fisik dan kesehatan}

Usia tua adalah periode penutup dalam rentang kehidupan seseorang, yaitu suatu periode dimana seseorang telah "beranjak jauh" dari periode terdahulu yang lebih menyenangkan, atau beranjak dari waktu yang penuh dengan manfaat. Bila seseorang yang sudah beranjak jauh dari periode hidupnya yang terdahulu, ia sering melihat masa lalunya, biasanya dengan penuh penyesalan, dan cenderung ingin hidup pada masa sekarang, mencoba mengabaikan masa depan secepat mungkin.

Manusia usia lanjut atau lansia dalam pemikiran banyak orang adalah manusia yang sudah tidak produktif lagi. Kondisi fisik rata-rata sudah menurun, sehingga dalam kondisi yang sudah uzur ini berbagai penyakit siap untuk menyerang mereka. Dengan demikian, di usia lanjut ini terkadang muncul semacam pemikiran bahwa mereka berada pada sisa-sisa umur menunggu datangnya kematian. Memasuki masa tua, sebagian besar lanjut usia kurang siap menghadapi dan menyikapi masa tua tersebut, sehingga menyebabkan para lanjut usia kurang dapat menyesuaikan diri dan memecahkan masalah yang dihadapi.

Sesuai dengan instrument yang telah disusun oleh peneliti yaitu format wawancara dan untuk mendapatkan data primer peneliti telah mengajukan beberapa pertanyaan kepada beberapa orang lansia yang ada di Kelurahan Pasar Tengah Curup. Dalam hal ini hasil wawancara dengan beberapa informen (lansia) sebagai berikut:

Menurut Bapak Sarimun (76 tahun) yang sudah tinggal lebih kurang lima puluh tabun di Kelurahan Pasar Tengah tepatnya di RT II/RWII "Usia lanjut (lansia) adalah orang yang yang sudah tidak produktif lagi dikarnakan kekuatan fisik dan daya pikir sudab menurun jadi apa saja yang di kerjakan nantinya hasilya akan

\footnotetext{
${ }^{9}$ Elizabeth B. Hurlock, Psikologi Perkembangan, Erlangga, Jakarta: 1980, hal. 380
} 
kurang baik sehingga dalam menyesuaiakan diri dengana menurunya kekuatan fisik dan kesehatan saya sering mengalami permasalahan terutama dari segi ekonomi karena kebutuhan keluarga semakain besar sedangkan tenaga semakain berkurang sehingga apa yang di hasilkan nantinnya kurang maksimal." 10

Dari pernyataan diatas membuktikan bahwa usia lanjut merupakan usia yang tidak produktif lagi dalam melakukan pekerjaan dikarnakan kekuatan fisik dan pikiran sudah memgalami penurunan. Kemudian pendapat informen lain mengenai permasalahan menurunya kekuatan fisik dan kesehatan yakni Ibu Musni (66 tahun); "Usia lanjut adalah usia yang sangat menjenuhkan dikarnakan sudah tidak dapat berbuat apa-apa lagi dikarnakan berkurangnya tenaga dan memasuki masa tua banyak berbagai penyakit yang mulai menyerang tubuh diantaranya sering masuk angin, maaq dan susah tidur". ${ }^{11}$

Dari pernyataan diatas dapat penulis simpulkan bahwa memasuki usia lanjut dirasakan sebagai usia yang sangat menjenuhkan dikarnakan keterbatasan fisik dan banyak penyakit yang mulai menyerang tubuh.

\section{Permasalahan pensiun dan berkurangnya income (penghasilan) keluarga}

Schwartz berkata bawa pensiun dapat merupakan akhir pola hidup atau masa transisi ke pola hidup baru, pensiun selalu menyangkut perubahan peran, perubahan keinginan dan nilai, dan perubahan secara keseluruhan terhadap pola hidup setiap individu.

Pensiun dapat saja berupa sukarela atau kewajiban yang terjadi secara reguler atau lebih awal. Beberapa pekerja menjalani masa pensiun secara sukarela, seringkali sebelum masa usia pensiun wajib. Hal ini mereka lakukan karaena alasan kesehatan atau keinginan untuk menghabiskan sisa hidupnya dengan melakukan hal-hal yang lebih berarti buat diri mereka dari pada pekerjaanya.

Masa usia lanjut tidak dapat digambarkan dengan jelas karena setiap individu berbeda-beda. Sikap-sikap sebelumnya, situasi kehidupan, dan kekuatan fisik mempengaruhi penyesuaian diri pada tahap-tahap terakhir kehidupan ini. Masalah-masalah utama dan penyebab gangguan kepribadian usia lanjut adalah keterbatasan fisik yang sangat ketat, ketergantungan, perasaan semakin kurang berguna, dan perasaan terisolasi. Dari hasil wawancara dengan Ibu Musni

"Permasalahan yang sering di hadapi biasanya berbubungan dengan ekonomi dikarnakan penghasilan yang tidak ada lagi dan hanya mengandalkan pemberian dari anak lebih lanjut beliau menjelaskan setelah memasuki masa pensiun beliau

\footnotetext{
${ }^{10}$ Hasil Wawancara Pada Hari Sabtu Tanggal 6 januari 2018

${ }^{11}$ Hasil observasi dan Wawancara Pada Hari Senin Tanggal 8 januari 2018
} 
agak mengalami kesulitan dalam membentuk bubungan sosial yang luas dikarnakan keterbatasan fisik.".12

Dari pernyataan dan pendapat diatas diketahui bahwa kesehatan, ekonomi dan keluarga merupakan salah satu permasalahan yang sering di hadapi pada masa lansia. Pada masa ini seringkali ada keadaan terpaksa, yakni ketergantungan fisik, sosial, dan ekonomi terutama kepada keluarga yang mungkin dipersulit dengan keadaan ditolak.

Masalah kesehatan mental pada lansia dapat berasal dari empat aspek yaitu fisik, psikologik, sosial dan ekonomi. Masalah tersebut dapat berupa emosi labil, mudah tersinggung, gampang merasa dilecehkan, kecewa, tidak bahagia, perasaan kehilangan, dan tidak berguna. Lansia dengan problem tersebut menjadi rentan mengalami gangguan psikiatrik seperti depresi, ansietas (kecemasan), psikosis (kegilaan) atau kecanduan obat. Pada umumnya masalah kesehatan mental lansia adalah masalah penyesuaian. Penyesuaian tersebut karena adanya perubahan dari keadaan sebelumnya (fisik masih kuat, bekerja dan berpenghasilan) menjadi kemunduran.

\section{Permasalahan menyesuaikan diri dengan kematian pasangan hidup.}

Sebagaian besar orang lansia perlu mempersiapkan dan menyesuaikan diri dengan peristiwa kematian suami atau istri. Kejadian seperti ini lebih menjadi masalah dengan peristiwa kematian suami atau istri. Dimana kematian suami berarti berkurangnya pendapatan dan timbul bahaya karena hidup sendiri dan melakukan perubahan dalam aturan hidup.

Seperti pemaparan dari ibu Musni berikut ini "Kematian pasangan hidup merupakan permasalahan yang sangat berat saya rasakan dikarnakan lebih kurang empat puluh tahun kita bersama dan beliau merupakan tulang punggung keluarga, setelah beliau tiada maka kami harus mencari nafkah sendiri.,"13

Berdasarkan pernyataan diatas dapat disimpulkan bahwa kematian pasangan hidup merupakan permasalahan yang dirasakan sangat berat terutama pada istri dikarnakan harus menggantikan posisi suami sebagai kepala keluarga atau pencari nafkah keluarga.

Tidak dapat disangkal lagi satu diantara penyesuaaian yang utama yang harus dilakukan oleh orang usia lanjut adalah penyesuaian yang harus dilakukan karena kehilangan pasangan hidup. Kehilangan tersebut dapat disebabkan oleh kematian atau perceraian walaupun umumnya lebih banyak disebabkan oleh kejadian kematian.menurup pak Husni Thamrin "kehilangan yang sangat berarti dalam hidup saya dikala kehilangan istri saya karena beliau merupakan penghibur dikala saya sedang sedih, motifataor dalam keluarga dan ibu yang terbaik bagi

\footnotetext{
${ }^{12}$ Hasil Observasi danWawancara Pada Hari Senin Tanggal 8 januari 2018

${ }^{13}$ Hasil Observasi danWawancara Pada Hari Senin Tanggal 8 januari 2018
} 
keluarga sehingga dengan tidak adanya beliau sekarang sering membuat hari-hari saya menjadi sepi." ${ }^{\prime 14}$

Berdasarkan hasil wawancara diatas dapat digambarkan berapa berartinya pasangan hidup di dalam hidup mereka terutama para lansia dimana mereka sering di hinggapi rasa kesepian. Karena alasan seperti itulah maka merupakan kebiasaan bagi wanita untuk menikah dengan pria yang umurnya sama atau lebih tua dan kerena rata-rata pria, meninggal lebih cepat dari pada wanita, maka menjanda dihari tua lebih sering terjadi pada wanita dari pada pria. Penyesuain terhadap kematian pasangan atau terhadap perceraian sangat sulit bagi pria maupun wanita pada usia lanjut, karena pada masa ini semua penyesuaian semakin sulit dilakukan.

\section{Permasalahan membentuk hubungan dengan orang-orang yang seusia.}

Pada lansia, mereka membangun ikatan dengan anggota dari kelompok usia mereka, untuk menghindari kesepian akibat ditinggalkan anak yang tumbuh besar dan masa pensiun. Menurut ibu Musni "Dalam membentuk hubungan dengan orang-orang seusia beliau mengatakan untuk membentuk hubungan dengan orang-orang seusia biasanya saya sering ikut dalam acara pengajian ibuibu yang sering diadakan seminggu sekali.", ${ }^{15}$

Berdasarkan pernyataan di atas dapat disimpulkan bahwa dalam membentuk hubungan dengan orang-orang seusia biasanya banyak mereka lakukan di tempat-tempat peribadatan. Dari hasil wawancara dengan Bapak Ali Amran ini mengenai usaha apa saja yang ia lakukan setelah memasuki masa pensiun ia mengatakan "Tidak banyak lagi usaha yang kita lakukan dikala kita sudah tua biasanya mendalami agama saja dan menjalankan pola hihup sehat agar kesehatan kita tetap terjaga dan jarang terserang berbagai macam penyakit".

Dari hasil ovservasi yang peneliti adakan terhadap Bapak Ali Amran dalam usahanya mengisi waktu luang setelah memasuki masa pensiun adalah selain mengikuti kegiatan keagamaan beliau juga aktif mengikuti senam pagi yang sering diadakan pada hari minggu pagi disana terlihat beliau sangat menikmati acara tersebut, selain itu beliau juga sering berkeliling kota curup dipagi hari dengan menggunakan sepeda, sekali-sekali peneliti juga sering melihat beliau dan istri berjalan santai di pagi hari sambil berbelanja sayuran di Pasar Atas.

Dalam membentuk hubungan dengan orang-orang seusia beliau sering mengikuti acara-acara pengajian dan juga sering mengikuti arisan perkumpulan keluarga Malalo yang sering diadakan sebulan sekali dimana dalam arisan

\footnotetext{
${ }^{14}$ Hasil Observasi dan Wawancara Pada Hari Sabtu Tanggal 13 januari 2018

${ }^{15}$ Hasil Observasi dan Wawancara Pada Hari Senin Tanggal 8 Januari 2018
} 
tersebut kita dapat berkumpul dengan sanak saudara sekampung, bercerita, dan mengenang masa muda dulu sesama kaum lansia.

\section{Permasalahan menyesuaikan diri dengan peran sosial yang luas.}

Pada lansia, individu mengalami perubahan peran. Dimana, para lansia mempunyai pengalaman lebih dari pada orang yang lebih muda, sehingga peran lansia biasanya diminta untuk memberi pendapat, masukan ataupun kritikan, dan partisipasi lansia terhadap kehidupan sosial. Pemberian peran tersebut akan membuat kesehatan fikir dan fisiknya akan terjaga baik. Termasuk mengurangi percepatan kepikunan.Untuk menyesuaikan diri dengan peran sosial yang luas dapat dilihat dari hasil wawancara peneliti dengan Bapak Ali Amran sebagai berikut:

"Memasuki masa tua untuk aktif dalam kegiatan sosial seperti hajatan, gotong royong membersibkan selokan dan lain-lain tidak lagi akan tetapi tetap hadir, tampil dan menampake.en muka dalam kegiatan tersebut dengan tujuan memberi semangat kepada yang muda-muda bahwa orang tua saja dapat aktif walaupun tidak bekerja apalagi yang muda-muda"

"Menurut ibu masni " untuk aktif dalam peran sosial mungkin tidak seperti masih muda dulu akan tetapi sekali-kali sering juga membantu apabila tetangga mengadakan hajatan."16

Berdasarkan hasil wawancara diatas, secara garis besar menerangkan bahwa untuk menyesuaikan diri dengan peran sosial yang lebih luas untuk aktif mungkin tidak seperti masih muda dahulu tetapi tetap hadir dan tampil dalam kegiatan tersebut.

Memahami perkembangan usia lanjut (lansia) adalah bentuk pembelajaran sekaligus pengorbanan pada orangtua. Karena, usia lanjut bagi sebagian orang adalah salah satu hal tak diinginkan. Ada perasaan takut. Takut merepotkan anak, tak bisa mengurus diri sendiri, jadi pemicu masalah dan banyak hal lainnya.

"Menurut Bapak Ali Amran "tidak banyak usaha lagi yang dapat kita lakukan dikala kita sudah tua dan biasanya dalam mengisi waktu luangnya ia banyak menghabiskan waktunya mendalami ilmi-ilmu agama dan ia berpendapat babwa sanya "dunia tidak mempengarubi lagi lebih fokus ke akherat" ${ }^{17}$

Hal senada juga diungkapkan oleh Bapak Sarimun

\footnotetext{
${ }^{16}$ Hasil Observasi danWawancara Pada Hari Rabu Tanggal 17 Januari 2018

${ }^{17}$ Hasil Observasi danWawancara Pada Hari Rabu Tanggal 17 Januari 2018
} 
"Setelah memasuki masa pensiun segala aktifitas perlahan-lahan berhenti sehingga segala pekerjaan yang kita lakukan di hari tua menjadi ngambang atau bingung dalam menjalankanya" ${ }^{\text {"18 }}$

Penjelasan diatas, bahwa tidak banyak usaha yang dapat dilakukan dikala kita memasuki masa lansia dan perlahan-lahan segala aktifitas kita akan berhenti. Hal yang sama diungkapkan oleh Bapak Husni Thamrin Dan Ibu Musni "memasuki masa pensiun mereka biasanya menghabiskan masa tuanya dirumah dan tempat-tempat ibadah" 19 Dari hasil wawancara terhadap para informan dapat digambarkan bahwa menyesuaikan diri dengan peran sosial yang luar biasanya banyak mereka lakukan di tempat-tempat peribadatan.

\section{Penutup}

Berdasarkan pembahasan yang telah diuraikan pada Bab-bab terdahulu, dapat penulis simpulkan bahwa permasalahan yang dialami lansia dalam penguasaan tugas-tugas perkembanganya di Kelurahan Pasar Tengah Curup. Dengan begitu, bahwa Kekuatan fisik dan kesehatan merupakan masalah utama yang sering dihadapi lansia yang ada di Kelurahan Pasar Tengah, karena kebutuhan keluarga masih besar sedangkan tenaga semakain berkurang sehingga apa yang di hasilkan nantinnya kurang maksimal.

Memasuki masa pensiun tidak banyak timbul permasalahan yang berhubungan dengan ekonomi keluarga dalam memenuhi kebutuhan sehari-hari sebab kebanyakan lansia yang ada di Kelurahan Pasar Tengah berpropesi sebagai pedagang dan masih melaksanakan aktifitasnya. Masalah kematian pasangan hidup merupakan permasalahan yang sangat berat dirasakan oleh para lansia karena mereka sering dihingagapi rasa kesepian dan terjadi perubahan peran diantara mereka.

Dalam membentuk hubungan dengan orang-orang seusia tidak terlalu mengalami hambatan, karena lansia yang ada di Kelurahan Pasar Tengah Curup biasanya sering mengikuti pengajian ataupun arisan. Permasalahan yang berhubungan dengan peran sosial yang lebih luas tidak terlalu mengalami banyak masalah, sebab lansia yang ada di Pasar Tengah masih di terima oleh segenap masyarakat.

\footnotetext{
${ }^{18}$ Hasil Observasi danWawancara Pada Hari Sabtu Tanggal 17 Januari 2018

${ }^{19}$ Hasil Observasi danWawancara Pada Hari Sabtu Tanggal 13 Januari 2018
} 


\section{Daftar Pustaka}

Aliyah B. Purwakania Hasan, Psikologi Perkembangan Islam, Jakarta: Raja Grapindo Persada, 2006

Amirul, Hadi Haryono, Metodologi Penelitian, Jakarta: Pustaka Setia, 1998

Chaidar al-wasilah.2006. Dasar-Dasar Merancang Dan Melakukan Penelitian Kualitatif. Jakarta: Pustaka Jaya

Diane E. Papalia, Dkk, Human Development ( Psikologi Perkembangan), Jakarta: Kencana, 2008

Elida Prayitno, Psikologi Orang Dewasa, Fakultas Ilmu Pendidikan UNP, Padang, 2000

Hurlock B.Elizabeth. Psikologi Perkembangan, Jakarta : Erlangga, 2005

Ketut Sukardi Dewa. 2002. Bimbingan Konseling Di Sekolah. Jakarta : Rineka Cipta, 2005

Nugroho. Perawatan Lanjut Usia, Jakarta: EGC, 1995

Matheu B. Miles et al. (Alih bahasa Tjejep Rohendi Rohidi), Analisis Data Kualitatif, Jakarta : UI Pers, 1992

Semium Yustinus, ofm Kesehatan Mental, Yogyakarta: Kanisius, 2006

Subrata Sumadi, Metodologi penelitian, Jakarta: Raja Grafindo Persada, 1995

Surunin, Ilmu Jiwa Agama, Raja Grafindo Persada, Jakarta , 2004

Winarno Suracmat, Pengantar ilmiah,Bandung: Tersito, 2015 